\title{
CHARACTERISTICS AND REALIZATION OF THE DIVIDEND POLICY OF COMPANIES QUOTED ON THE WARSAW STOCK EXCHANGE FOR THE PERIOD 2008-2017
}

\author{
Bartlomiej Jabłoński \\ e-mail: bartlomiej.jablonski@ue.katowice.pl \\ ORCID: 0000-0002-9398-017X \\ (C) 2019 Bartłomiej Jabłoński \\ DOI: 10.15611/fins.2019.3.01 \\ JEL Classification: F21, G32, G35, O16
}

University of Economics in Katowice, Katowice, Poland

This is an open access article distributed under the Creative Commons Attribution-NonCommercialNoDerivs license (http://creativecommons.org/licenses/by-nc-nd/3.0/)

\begin{abstract}
The article takes up the issue of the characteristics and the implementation of the dividend policy of companies quoted on the Warsaw Stock Exchange in Warsaw for the period 2008-2017. The purpose of the research is the characteristics of dividend policy company satisfaction mechanism, including an assessment of its actual implementation. To study the characteristics and implementation of the dividend policy by the company's dividend, eventually it was necessary to classify the companies that during the period of 2009-2018 paid dividends for the period 2008-2017 without a break (at 31.07.2018). The test results indicate a high average annual growth rate of paid dividends. Unfortunately, more than half of the companies developed a dividend policy and those that have it as the basis for their decision on the amount of payment of dividends indicate net profit and investment needs.
\end{abstract}

Keywords: dividend policy, dividends, investments, capital markets.

\section{Introduction}

Stock market issuers announcing the dividend policy not only communicate the financial result to the six-year audience, but also try to tie the capital market investors together, in particular investors taking investment decisions on the basis of fundamental factors. The most appropriate distribution channel for such information are websites with a dedicated section for investors (often under the name of investor relations), current and periodic, or handouts.

The aim of the article is a presentation of the research on the characteristics and the implementation of the dividend policy of the listed companies on the Warsaw Stock Exchange which during the period of 2009-2018 paid dividends without 
interruption for the period of 2008-2017. This criterion has made it possible to research only those companies that for the last 10 years have paid dividends without interruption. The intention of the author was to identify the specific characteristics of these companies from the point of view of a description of the dividend policy, the extent of its implementation, as well as the specificities of the same dividend.

The study was carried out in the following stages:

1. First stage - selection of companies: companies belonging to WIG, which paid dividends every year for the period 2008-2017.

2. Second stage - preliminary studies of issuers: a study of the average dividend paid per share, and the average annual growth rate of dividends.

3. Third stage - examination of the relevant issuers: evaluation of the quality of the communication policy on dividends, dividend policy and the dividend policy of the selected listed companies.

\section{Strategies and models for payment of dividends}

Investors can conduct a fair review of the issuer, and consciously make investment decisions on the basis of reliable information provided by the listed companies. A part of this is in the logic of the purposes of investor relations, which should include:

- filling out information obligations required by law,

- information about the company's activities,

- getting the right market valuation,

- reduction in cost from the capital,

- open communication of financial results,

- information about the company's development plans.

In the literature of the subject one will notice the inclusion of investor relations as the focus on the dialogue between the company and the environment for investors, and the provision of objective information on the activities of the company [Czerwińska 2004]. In another step, investor relations means taking action to ensure that the company's shares reach the right market price, so that the gap between reality and the view of how the company is seen will be compensated [Seitel 2003, p. 504]. How the company is perceived by investors is particularly important if they engaged capital in the long term, and regardless of the trading downturn count on dividends. The research conducted by Rubin and Spaht II [Rubin, Spaht 2011, pp. 11-19], and Williams and Miller [Williams, Miller 2013, pp. 58-69], and Fuller and Goldstein [Fuller, Goldstein 2011, pp. 457-473] confirms the legitimacy of such investments, because regardless of the fluctuations in prices on the capital market, dividends are a hedge against the depreciation of securities in the portfolio's value. This is particularly relevant during a bear market because the shares satisfaction mechanism is then characterized by smaller declines. There is also the recurrent note on the constant, positive communication carried out directly or indirectly between 
a company owned by the public and its owners [Gregory1997, p. 74]. Whatever the definition of investor relations, an important fact is correct - to support investors in any interim and the planned events that may affect investment decisions. This also includes a description of the dividend policy applied by the issuer, the historical dividend payment and current information in this regard. That is why the boards should in the section of investor relations, present not only the historical dividend, but also communicate the principles, constraints, and possible strategies for the payment of dividends. They may have some general solutions widely described in the literature [Brigham, Houston 2015, p. 204; Brealey, Myers 2003, p. 438; Baker, Powell, Veit 2002, Benninga, Sarig 2000, p. 285, Horbaczewska 2012; Wilimowska, Wilimowski 2001, pp. 452-453], known as dividend strategy. The payment of dividends may be made up of the following:

- strategy for stable dividends - the company pays at a fixed dividend time, without changes in short periods,

- the strategy of a stable dividend payment ratio - the company shall pay the specified fixed percentage of the profits in the form of dividends, which depending on the achieved financial results change paid dividends per share (DPS),

- residual dividend strategy - the dividend shall be paid from the amount remaining after implementation of all economically justified investment projects,

- the synergy strategy fixed dividend and the irregular extra (the so-called compromise strategy); the issuer shall determine the fixed low amount of dividends and an irregular one based on profits and demand for capital, which changes the paid dividend per share,

- the strategy for $100 \%$ payment of profit strategy, difficult to implement by the company in the long term due to the continuous transfer of high amounts without taking into account the development needs of the entity,

- the strategy for zero-dividend - the company does not pay dividends, often used when it is calculated that the profits are not enough for the investment projects planned in the budget.

Modelling solutions can also be helpful for policy dividends. A. Szablewski [Szablewski (ed.) 2000, p. 22] offered a solution with which it is clear that the start of dividend policy analysis should take place from determining whether the entity has paid dividends so far, and if so, what was their value and the size of the company it could have actually afforded. Further stages include reference to efficiency, determining FCFE dividends available investment projects and comparing ROE to WACC and the cost of equity capital.

A slightly different solution was presented in the Damodaran [Damodaran 2007, p. 423] model, from which it is apparent that the company should determine the target and the current long-term payout ratio. Any adjustment can be done by paying an additional dividend or buying shares (the aim of buy-back). This solution assumes:

1. An indication of what the company generated in net cash flows in the past, how much was paid in dividends and how many of its own shares a company redeemed for redemption. 
2. Evaluating the results of the implemented investment projects measured the relationship between the rate of return on equity and the entire invested capital to the weighted average cost of capital and cost of capital.

3. Determine what new investment projects the entity has, and consider them from the point of view of creating shareholder value.

4. The decision to limit the payment of dividends, the company carried out the relevant investment choices in the past and has profitable investment projects for the future.

5. Making decisions on payment of dividends, the company has made wrong choices in the past and present - temporarily the lack of compelling investment projects.

A residual policy strategy was used in the algorithm proposed by Z. Wilimowska and M. Wilimowski [Wilimowska, Wilimowski 2001, p. 463]. In the solution, the only financial results exceeding investment gives you the ability to pay dividends. It is worth noting that in the literature of the subject one can notice different ways to specify the amount of the dividend payout ratio, depending on the approach adopted to indicators related to FCFE [Szablewski (ed.) 2000, p. 22; Cwynar, Cwynar 2007, p. 214] or traditionally the net profit [Brigham, Houston 2005, p. 207]. It also indicates the residual dividend policy model modifications [Jajuga, Słoński 1997, pp. 297-298].

The result of applying the first of those (a variant of 'good') is a constant curve with small fluctuations in dividend per share. Another variant is assumed, in turn, to have become a payout ratio of dividends with establishing its size at a level that does not interfere with long-term investment decisions. Brigham and Houston [Brigham, Houston 2005, pp. 203-204] state that assuming a rigidly applied policy dividends residual, one can calculate the amount of the dividends in the following way:

$$
\begin{gathered}
\text { Dividends }= \\
\text { net profit - } \\
\text { profit stopped the purpose of finance new investment }= \\
\text { net profit }- \\
\text { (target equity } \cdot \text { investment total budget). }
\end{gathered}
$$

In turn, with the model presented by Lintner [Brealey, Myers 2003 p. 579] it follows that the dividend partly depends on the current profits of the enterprise and partly also from the dividend paid in the previous year. This model can be written as:

$$
\begin{gathered}
\qquad D I V_{1}-D I V_{0}= \\
\text { rate change dividends } \cdot \text { target change }= \\
\text { the rate of change of dividends } \cdot\left(\text { target dividend rate } \cdot E P S_{1}-D I V_{0}\right),
\end{gathered}
$$

where: $D I V_{1}$ - the dividend paid in the coming year; $D I V_{0}$ - dividend paid in the previous year; $E P S_{1}$ - earnings per share. 
From the strategy and from the profit-sharing models, it can be concluded that the policy of paying small fixed dividends which have dropped in value is a compromise between a stable dividend and fixed rate payment because, on the one hand, this gives the management board flexibility and, on the other hand, investors can count on at least the minimum dividend. In addition, it is difficult to determine which solution is best for a company or group of companies from the industry. Despite this, a company quoted on the Stock Exchange seeks to manifest the dividend policy in different ways. However it remains contentious whether, and to what extent, the company's dividend follows the adopted dividend policy.

\section{Implementation of the policy on dividends in companies quoted on the stock exchange - survey results}

The studies covered companies whose shares are listed on the Warsaw Stock Exchange and are part of WIG. In order to identify companies satisfaction mechanism, out of the 459 companies who paid dividends during the period of 2009-2018 were those which for the last 10 years paid dividends without interruption. This means that to study the characteristics and the implementation of the policy of dividends regarding the company's dividend classified these companies that during the period of 2009-2018, paid dividends for the period 2008-2017 without a break (at 31.07.2018). In this way we selected 13 companies. Thus requiring the criterion for the selection of companies is dictated by the need to analyse the actual companies satisfaction mechanism, which share out the profit without fail in the long term.

In addition, this criterion enables to examine the characteristics and implementation of policy dividends and the dividend growth for companies which were selected by a more stringent criterion than the rules adopted on the Warsaw Stock Exchange for companies that are assigned to the WigDiv index (in the last 5 years, it quotes payment of dividends for at least 3 years). The purpose of the research is the characterization of the dividend policy company satisfaction mechanism, including an assessment of its actual implementation. For these tests the following hypotheses were adopted:

$\mathrm{H}_{0}$ : there are companies listed on the Warsaw Stock Exchange which by paying dividends for the period 2008-2017 comply with the adopted dividend policy,

and

$\mathrm{H}_{1}$ : there are no listed companies in the Warsaw Stock Exchange which by paying dividends for the period 2008-2017 applied the adopted dividend policy.

Table 1 shows the companies along with the amount of paid annual dividends, which made systematic payments to shareholders, for the period 2008-2017. 
Table 1. Dividends paid by companies listed on the Warsaw Stock Exchange for the period 2008-2017 [PLN]

\begin{tabular}{|l|c|c|c|c|c|c|c|c|c|c|}
\hline \multicolumn{1}{|c|}{ Company } & 2008 & 2009 & 2010 & 2011 & 2012 & 2013 & 2014 & 2015 & 2016 & 2017 \\
\hline Apator & 0.25 & 0.5 & 0.6 & 0.75 & 1.4 & 0.6 & 0.5 & 1 & 1.1 & 1.2 \\
\hline AssecoPol & 1.03 & 1.47 & 1.8 & 2.19 & 2.41 & 2.6 & 2.9 & 3.01 & 3.01 & 3.01 \\
\hline ATMGrupa & 0.16 & 0.08 & 0.18 & 0.12 & 0.02 & 0.16 & 0.91 & 0.22 & 0.22 & 0.22 \\
\hline Budimex & 5.84 & 6.8 & 9.08 & 10.97 & 4.39 & 11.85 & 6.11 & 8.14 & 14.99 & 17.61 \\
\hline DomDev & 0.8 & 0.8 & 0.9 & 1.5 & 3.68 & 2.2 & 2.25 & 3.25 & 5.05 & 7.6 \\
\hline Eurcash & 0.3 & 0.37 & 0.37 & 0.18 & 0.9 & 0.79 & 0.79 & 1 & 0.73 & 0.73 \\
\hline Eurotel & 1.05 & 1.2 & 1.4 & 1.5 & 1.6 & 1.84 & 1 & 1.4 & 1.9 & 2.2 \\
\hline Neuca & 1.85 & 2 & 2.3 & 2.6 & 3.2 & 3.8 & 4.33 & 5 & 5.75 & 6.4 \\
\hline Pulawy & 4.3 & 8.15 & 1 & 3.66 & 9.4 & 10.38 & 7.03 & 10.5 & 6.2 & 4.46 \\
\hline Sniezka & 1.35 & 1.6 & 1.7 & 1.35 & 2.5 & 2.5 & 3.1 & 3.15 & 3.2 & 2.2 \\
\hline Unibep & 0.1 & 0.1 & 0.12 & 0.12 & 0.12 & 0.12 & 0.15 & 0.17 & 0.2 & 0.2 \\
\hline Wawel & 10 & 10 & 10 & 11 & 14 & 20 & 20 & 20 & 20 & 25 \\
\hline Zywiec & 20 & 48 & 65 & 33 & 31 & 18 & 5 & 35 & 29 & 26 \\
\hline
\end{tabular}

Source: own work based on Web pages and documents

Table 2 presents the parameters of the companies taking into account the average growth rate of paid dividends, the average dividend per share and the sum of the payments.

Table 2. The growth rate of the dividends for companies listed on the Warsaw Stock Exchange for the period 2008-2017

\begin{tabular}{|l|c|c|c|}
\hline \multicolumn{1}{|c|}{ Company } & $\begin{array}{c}\text { Sum of dividends paid } \\
\text { (PLN) }\end{array}$ & $\begin{array}{c}\text { Average dividend } \\
\text { (PLN) }\end{array}$ & $\begin{array}{c}\text { Average growth rate } \\
\text { of paid dividends (\%) }\end{array}$ \\
\hline Apator & 7.9 & 0.79 & 30.77 \\
\hline AssecoPol & 23.43 & 2.343 & 13.34 \\
\hline ATMGrupa & 2.29 & 0.229 & 29.68 \\
\hline Budimex & 95.78 & 9.578 & 37.43 \\
\hline DomDev & 28.03 & 2.803 & 39.93 \\
\hline Eurcash & 6.16 & 0.616 & 11.73 \\
\hline Eurotel & 15.09 & 1.509 & 14.86 \\
\hline Neuca & 37.23 & 3.723 & 42.57 \\
\hline Pulawy & 65.08 & 6.508 & 9.48 \\
\hline Sniezka & 22.65 & 2.265 & 8.44 \\
\hline Unibep & 1.4 & 0.14 & 11.68 \\
\hline Wawel & 160 & 16 & 64.28 \\
\hline Zywiec & 310 & 31 & 33.15 \\
\hline Average value & 59.62 & 5.96 & \\
\hline
\end{tabular}

Source: own work based on Web pages and documents. 
Initial analysis of the issuer indicates that the average dividend growth rate is mostly characterized by ATMGrupa, Żywiec and Puławy. In turn, the results above the average for the test group of companies (the average annual growth rate of dividends is $33.15 \%$ ) was achieved by five companies, which makes $38.46 \%$ of the surveyed entities.

It should be noted that the test group of companies is characterized by high average annual growth rate of dividends ${ }^{1}$, and no company showed negative values. This means that each of the satisfaction mechanism companies paid dividends during the period, with average annual positive growth dynamics. The average paid dividend per share is in the case of four companies (Budimex, Puławy, Wawel and Żywiec) higher than the average for the group (\$ 5.96). For investors in the capital market, in addition to the history of dividend payments is essential whether the company has a policy of dividends on the basis of which withdrawals were made and the extent to which these payments were consistent with it. A high degree of application of the dividend policy means to the investor the possibility of prediction for the payment of dividends in the future, and thus assess the attractiveness of investment in such companies. To this end, further studies have been made of the quality of communication of the dividend policy by the company. Table 3 shows the results of the analysis of the quality of dividend policy's communication of companies listed on the Warsaw Stock Exchange for the period 2008-2017.

Table 3. Criteria for the evaluation of the quality of the dividend policy's communication by the companies recorded on the Warsaw Stock Exchange for the period 2008-2017

\begin{tabular}{|c|c|}
\hline \multicolumn{1}{|c|}{ Criteria for the analysis of dividend policy } & Share (\%) \\
\hline $\begin{array}{c}\text { 1. Dividend policy clearly described on the issuer's website or the company's } \\
\text { documents }\end{array}$ & 30.77 \\
\hline $\begin{array}{l}\text { 2. A general statement that the dividend is recommended by the Board, the } \\
\text { Board of Directors or that the general meeting of shareholders is approved }\end{array}$ & 15.38 \\
\hline 3. No dividend declaration & 53.85 \\
\hline
\end{tabular}

Source: own work based on Web pages and documents.

The study includes the following critical points:

- transparency of the description of the dividend policy on the website of the company,

- a detailed description of the dividend policy, a description of the dividends in all other policy documents of the issuer.

Figure 1 shows the results of the analysis of the dividend policy for the investigated companies.

1 In theory and practice, it is assumed that attractive to investors average annual dividend growth rate is a few percentage points above the annual rate of inflation in the country. 


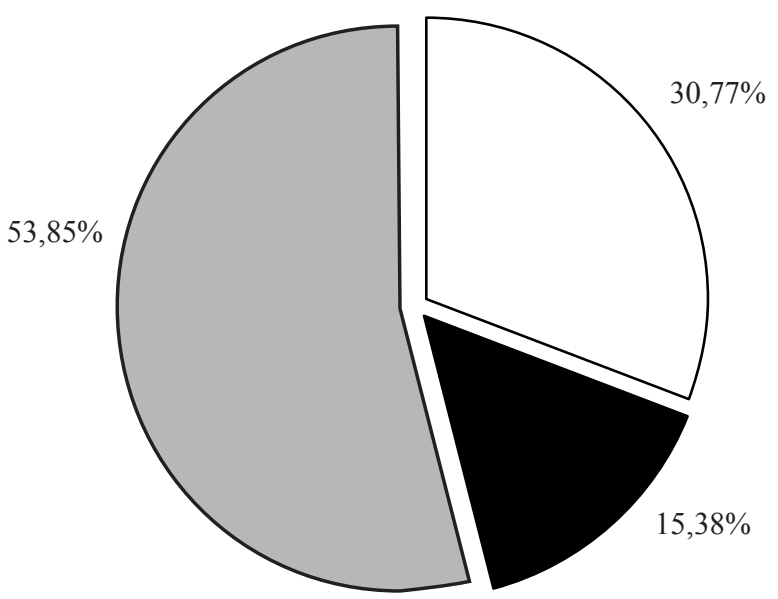

$\square$ Divident policy clearly described on the issuer's website or the companys document.

A general statement that the divident is recommendet by the Board, the Board of directors or it is approved by the general meeting of sharehoolders.

No dividend declaration.

Fig. 1. Results of the evaluation of the quality of dividend policy communication by companies listed on the WSE for the period 2008-2017

Source: own elaboration.

The results of the evaluation study of the quality of dividend policy communication by the investigated companies are disappointing. Given that it is mentioned that dividend-paying companies, as one of the most important points of the investor relationship, should take into account the clear description of the dividend policy, more than half of them (53.85\% of the issuers surveyed) do not declare dividends being paid. Only $30.77 \%$ of companies clearly describe the principles of distribution of the financial result, and $15.38 \%$ generally state that the dividend is recommended by the Board, the Board of Directors or that it is approved by the general meeting of shareholders. By grouping the results obtained into unequivocally positive or negative, the share of the latter is even greater (Table 4).

Table 4. Summary evaluation of the quality of the dividend policy communication by companies listed on the WSE for the period 2008-2017

\begin{tabular}{|l|c|}
\hline \multicolumn{1}{|c|}{ Company characteristics } & Share (\%) \\
\hline 1. Companies opening the dividend policy & 30.77 \\
\hline 2. Companies not transmitting information on the dividend policy & 69.23 \\
\hline
\end{tabular}

Source: own elaboration. 
As many as $69.23 \%$ of the companies investigated do not provide specific information about the dividend policy, even though the dividends have been paid systematically for at least 10 years.

The remainder of the study refers to the policy characteristics of the dividends, with the note that it concerns only those companies which, according to the earlier stage of the analysis (Table 4), were classified in the group of companies openly informing about their dividend policy (Table 5).

Table 5. Characteristics of the dividend policy of dividend companies listed on the WSE for the period 2008-2017

\begin{tabular}{|l|c|}
\hline \multicolumn{1}{|c|}{ Dividend policy characteristics } & Share (\%) \\
\hline 1. Reference to net profit & 20.00 \\
\hline 2. Reference to net profit and investment expenditure & 60.00 \\
\hline 3. Reference to net profit and available cash & 20.00 \\
\hline
\end{tabular}

Source: own elaboration.

Most of studied companies $(60 \%)$ refer to the dividend policy as to the financial parameter at the level of net profit and cash requirements for investments. Equally, $20 \%$ of the other companies refer to net profit or net profit and available cash without indicating which events (e.g. investments, current costs, need to maintain liquidity) are taken into account when determining dividends. The next phase of the study focused on the implementation of dividend policy. It examined the extent to which the company paid dividends in accordance with the declared dividend policy. The group of companies which were classified at the initial stage of the survey as having and informing the dividend policy was divided into three groups:

1. Group 1 - companies that pay dividends in accordance with the accepted rules described in the declared dividend policy.

2. Group 2 - companies that pay dividends in the middle of the period under consideration according to the accepted rules described in the declared dividend policy and, in the remainder of the time, the dividends differed significantly.

3. Group 3 - companies that pay dividends that are completely different from the rules described in the declared dividend policy.

Table 6 presents the results of the study of the companies grouped in terms of the degree of implementation of the adopted dividend policy.

Table 6. Implementation of the dividend policy by companies listed on the WSE for the period 2008-2017

\begin{tabular}{|l|c|}
\hline \multicolumn{1}{|c|}{ Implementation of dividend policy } & Share (\%) \\
\hline 1. Dividend payouts in accordance with the agreed dividend policy & 33.33 \\
\hline 2. Dividend payouts in half according to the agreed dividend policy & 50.00 \\
\hline 3. Dividend payouts not in line with the accepted dividend policy & 16.67 \\
\hline
\end{tabular}

Source: own elaboration. 
A further phase of the research carried out among the dividend-paying companies informing about their dividend policy indicates positive trends in this group of entities. More than $80 \%$ of issuers (83.33\%) informing about the adopted dividend policy pay dividends in accordance (or at least halfway) with the accepted rules for the distribution of financial results. Only $16.67 \%$ of companies pay dividends not according to the declared dividend policy. This means that an investor who deliberately selects a dividend company in an investment portfolio, with the declared dividend policy in investor relations or other corporate relations, throughout can rely heavily on the company's use to the adopted distribution of the financial result.

The study drew attention to one more parameter related to dividend payout the average rate of dividend growth. The final stage of the study was the analysis of whether the company's dividend policy relates to the increase in dividends paid. According to the results of the study (Table 2), selected companies paid dividends characterised by a high average annual growth rate. Table 7 presents an analysis of the dividend policy record, including the rate of dividend growth taking into account the rate of dividend growth in the dividend policy of the companies analysed for the period 2008-2017.

Table 7. Taking into account the rate of dividend growth in dividend policy of the companies analysed for the period 2008-2017

\begin{tabular}{|l|c|}
\hline \multicolumn{1}{|c|}{ Taking into account the rate of dividend growth in dividend policy } & Share (\%) \\
\hline Yes & 33.33 \\
\hline No & 66.67 \\
\hline
\end{tabular}

Source: own elaboration.

According to the results of the most recent research phase, more than half of the companies (66.67\%) do not describe in the adopted dividend policy a plan to pay growing dividends. It is worth noting that companies do not plan to pay growing dividends, although in the vast majority they not only make such payments, but this is also systematically increased over the last 10 years of research (Table 2). Such issuers will appreciate not only during a bull period, but also the consequence of the payment of rising dividends would result in increased demand, especially when the stock prices of companies in a bear marked are characterised by a downward trend.

\section{Conclusions}

On the basis of surveys of dividend-paying companies quoted on the stock exchange, their specific characteristics may be indicated. First of all, the tested group is characterised by a high average annual growth rate of dividends. For any of the companies investigated, a negative average annual dividend change cannot be attributed. Unfortunately, more than half of the companies do not have a structured 
dividend policy that would help investors assess the merits of their investment in their shares. The absence of a declaration of dividends in this group of companies, despite their systematic disbursements, should be considered disappointing. If companies with dividend policies are to be taken into consideration, this is mainly related to net profit and investment needs.

For a positive outcome, it should be considered that those issuers who have a developed dividend policy will in most cases pay dividends in accordance (or at least halfway) with the accepted principles of the distribution of their financial results. It is worth noting that more than half of companies do not describe in the adopted dividend policy a plan to pay growing dividends.

Studies and analyses carried out show that despite some negative features of companies related to dividend policy, there are listed companies in the Warsaw Stock Exchange paying dividends for the period 2008-2017 applied the adopted dividend policy. Moreover, they are trying to pay dividends with an average annual growth rate significantly exceeding the annual inflation rate.

It is worth noting that the study concerned a specific group of companies which, with subsequent dividend payment periods, should be extended. In the analysed period, after 22 companies paid dividends 9 and 8 times, 33 companies shared out a share of investor profit for 7 years and 36 companies for 6 years. Assuming that these companies will continue to pay dividends, the number of companies constantly dividing their financial result, and thus investors will have greater opportunities to choose companies for their securities portfolio.

It should also be noted that the studies carried out do not close the researched problem and should be extended to studies of the international market also taking into account just those companies which are constantly paying dividends. It also seems appropriate to compare the results of this research with national and international markets.

\section{References}

Baker H.K., Powell G.E., Veit E.T., 2002, Revisiting managerial perspectives on dividend policy, Journal of Economics and Finance, vol. 26, no. 3.

Benninga S.Z., Sarig O.H., 2000, Finanse przedsiębiorstwa. Metody wyceny, WIG-Press, Warszawa. Brealey R.A., Myers S.C., 2003, Principles of Corporate Finance- Ed. 7, McGraw-Hill, New York. Brigham E.F., Houston J.F., 2015, Zarzqdzanie finansami, PWE, Warszawa.

Cwynar A., Cwynar W., 2007, Kreowanie wartości spótki poprzez dtugoterminowe decyzje finansowe, Wydawnictwo Wyższej Szkoły Informatyki i Zarządzania, Warszawa.

Czerwińska T., 2004, Relacje inwestorskie w spółkach notowanych na Giełdzie Papierów Wartościowych w Warszawie, Prace i Materiały Wydziału Zarządzania Uniwersytetu Gdańskiego „Inwestycje i Nieruchomości” nr 1, Gdańsk.

Damodaran A., 2007, Finanse korporacyjne. Teoria i praktyka, Helion, Gliwice.

Dziawgo D., 2011, Relacje inwestorskie, PWN, Warszawa. 
Fuller K.P., Goldstein M.A., 2011, Do dividends matter more in declining markets?, Journal of Corporate Finance, vol. 17, no. 3, pp. 457-473.

Gregory A., 1997, Public Relations w praktyce, WPSB, Kraków.

Horbaczewska B., 2012, Wypłaty dla akcjonariuszy a wycena akcji na rynku kapitałowym, CeDeWu, Warszawa.

Jajuga T., Słoński T., 1997, Finanse spółek. Długoterminowe decyzje inwestycyjne i finansowe, Wydawnictwo Akademii Ekonomicznej we Wrocławiu, Wrocław.

Rubin H., Spaht II C., 2011, Financial independence through dollar cost averaging and dividends reinvestment, Journal of Applied Business and Economics, no. 4, pp. 11-19.

Seitel F.P., 2003, Public relations w praktyce, Felberg, Warszawa.

Szablewski A. (ed.), 2000, Strategie wzrostu wartości firmy. Studium przypadków, Poltext, Warszawa.

Williams A., Miller M., 2013, Do stocks with dividends outperform the market during recession, Journal of Accounting and Finance, vol. 13, no. 1, pp. 58-69.

Wilimowska Z., Wilimowski M., 2001, Sztuka zarzadzania finansami - cz. 2, Oficyna Wydawnicza Ośrodka Postępu Organizacyjnego, Bydgoszcz.

\section{CHARAKTERYSTYKA I REALIZACJA POLITYKI DYWIDEND PRZEZ SPÓŁKI DYWIDENDOWE NOTOWANE NA GIEŁDZIE PAPIERÓW WARTOŚCIOWYCH W WARSZAWIE ZA OKRES 2008-2017}

Streszczenie: Artykuł podejmuje problematykę charakterystyki oraz realizacji polityki dywidend przez spółki dywidendowe notowane na Giełdzie Papierów Wartościowych w Warszawie za okres 2008-2017. Celem badań jest charakterystyka polityki dywidend spółek dywidendowych włącznie z oceną jej faktycznej realizacji. Do badania charakterystyki i realizacji polityki dywidend przez spółki dywidendowe zaklasyfikowano ostatecznie te spółki, które w okresie 2009-2018 wypłacały dywidendy za okres 2008-2017 bez przerwy (stan z 31.07.2018). Wyniki badań wskazują na wysokie średnie roczne tempo wzrostu wypłacanych dywidend. Niestety ponad połowa spółek nie ma opracowanej polityki dywidend, a te, które ją mają, za podstawę decyzji o wysokości wypłaty dywidend przyjmują zysk netto i potrzeby inwestycyjne.

Slowa kluczowe: polityka dywidend, dywidenda, inwestycje, rynki kapitałowe. 